\title{
Smart and Sustainable Hair Products Based on Chitin-Derived Compounds
}

\author{
Pierfrancesco Morganti ${ }^{1,2, *}$, Gianluca Morganti ${ }^{3}$ and Maria-Beatrice Coltelli ${ }^{4, *}$ (D) \\ 1 Academy of History of Healthcare Art, 00186 Rome, Italy \\ 2 China Medical University, Shenyang 110000, China \\ 3 ISCD Nanoscience Center, 00165 Rome, Italy; lucamorgan@libero.it \\ 4 Department of Civil and Industrial Engineering, University of Pisa, 56122 Pisa, Italy \\ * Correspondence: pierfrancesco.morganti@iscd.it (P.M.); maria.beatrice.coltelli@unipi.it (M.-B.C.)
}

check for updates

Citation: Morganti, P.; Morganti, G.; Coltelli, M.-B. Smart and Sustainable Hair Products Based on

Chitin-Derived Compounds.

Cosmetics 2021, 8, 20. https://

doi.org/10.3390/cosmetics8010020

Received: 29 January 2021

Accepted: 1 March 2021

Published: 9 March 2021

Publisher's Note: MDPI stays neutral with regard to jurisdictional claims in published maps and institutional affiliations.

Copyright: (c) 2021 by the authors. Licensee MDPI, Basel, Switzerland. This article is an open access article distributed under the terms and conditions of the Creative Commons Attribution (CC BY) license (https:/ / creativecommons.org/licenses/by/ $4.0 /)$.

\begin{abstract}
According to previous research studies, consumers worldwide are searching for new natural-oriented hair products that are both skin and environmentally friendly. Worldwide waste and air pollution, with the consequent environmental disasters, represent the greatest risk to human health and economy, further increased by the COVID-19 pandemic. Among others, non-biodegradable molecules are present in hair products (fossil-based additives, surfactants, etc.) and macromolecules (plastics). Plastics waste is considered the most serious problem, representing a forecast amount of 460 million tons per year by 2030,12\% of which is reused or recycled. Most plastics consumed, therefore, go to landfills and incineration, also if their recycling is considered an important driver of industrial profitability. Thus, the use of biopolymers represents an interesting alternative to produce biodegradable goods and tissues. After an introduction to the worldwide waste problem and the hair structure, the present review proposes the possibility to make biodegradable tissues that, realized by chitin nanofibrils and nano-lignin as natural polymers, may be used to produce an innovative and smart cosmetic hairline. Chitin-derived compounds are considered interesting polymers to produce non-woven tissues able to repair the hair damages provoked by the aggressiveness of both the environment and some aggressive cosmetic treatments, such as setting, bleaching, permanent waving, and oxidative coloring. The possible activity, that positively charged polymers such as chitin could have, has been speculated, interfering with the constitution and organization of the hair fibrils' structure, which is negatively charged. The possibility of selecting biopolymers for their packaging is also discussed. Moreover, the use of these biopolymers, obtained from forestry-agro-food waste, may be of help to safeguard the further consumption of natural raw materials, necessary for future generations, also maintaining the earth's biodiversity.
\end{abstract}

Keywords: chitin nanofibril; nano-lignin; waste; plastics; cosmetics; hair; non-woven tissue; natural fiber

\section{Introduction}

According to previous research studies, the evolution of cosmetic product formulations and packaging can exponentially favor the market worldwide, especially in the AsiaPacific area (APAC) [1-4]. APAC consumers, in fact, are increasingly placing a high importance on hair and scalp health, searching for innovative and specialized products that offer outstanding performances. These products are preferentially made with renewable, natural, and eco-friendly ingredients and improve frizziness and protect hair from humidity, pollution, stress balance, and excessive sebum levels, with the aim to support the scalp's protective barrier and help to maintain clean, healthy-feeling hair [2]. Thus, most of the hair care segment's consumers are looking for sustainable, science-based, and natural-oriented products, all characteristics that influence their purchase decisions [2,3]. The products must address the signs of damage and the aging phenomena by combatting and restoring texture and repairing the hair strength. Moreover, these cosmetics would give shine and a 
youthful appearance to the hair, thus nourishing and restoring its softness and smoothness, simplifying the routine washing and all the other topical treatments also (Figure 1) [1,2,4].

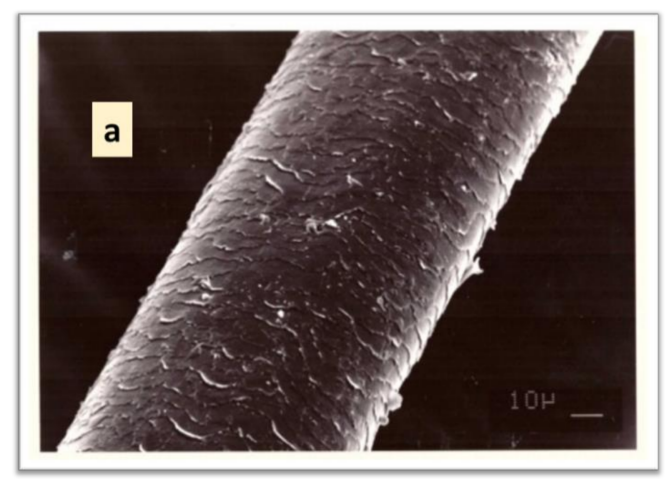

(a)

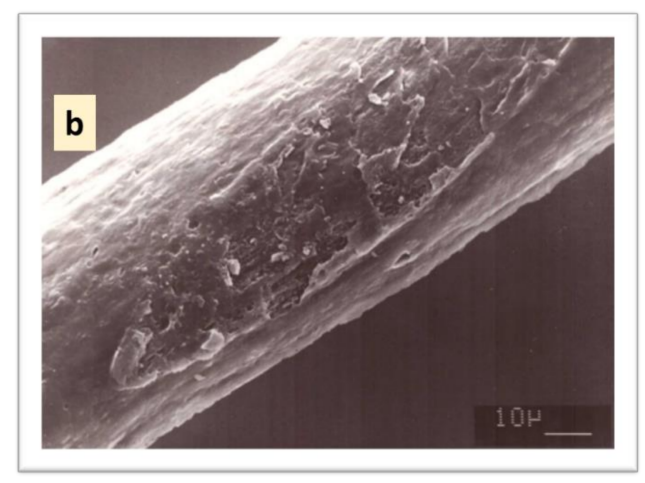

(b)

Figure 1. Hair structure. (a) Hair cuticle consisting of thin keratinized scales regularly disposed of as a plain tiles roof. (b) Scanning Electron Microscopy (SEM) image of hair free of scales eliminated from its surface by frequent washing and combing.

Therefore, for this category of cosmetics, consumers expect a basic functionality, having, for example, the possibility to mimic the natural hair's protective lipid layer in order to control "frizz and volume, defining curls even after extreme humidity to mend split ends as much as possible after just one application" [3]. According global market researches, $22 \%$ of UK men think it is important that their beauty/grooming routines may be able to promote physical health and $14 \%$ mental health, while $28 \%$ (30\% in Poland, $29 \%$ in Italy, and $27 \%$ in Portugal) are willing to increase the number of products they use to improve their appearance [2]. However, while for $32 \%$ of consumers it is important to protect/repair damaged hair, $46 \%$ consider hair fall and 50\% the cosmetic impact. Thus the necessity to avoid chemicals, protecting scalp and hair by sustainable, science-oriented products [2-4]. Anti-aging products and e-commerce are further pushing hair and beauty market growth, together with luxury products.

Eco-friendly packaging is as important to the consumer as cosmetic products developed by ecological standardization and natural resources to preserve the environment [3,4]. More than 120 billion units of cosmetic packaging, in fact, are produced every year by the global cosmetics industry, around $60 \%$ of which are made by non-biodegradable plastics. Thus, it has been estimated that if this level of consumption continues, by 2050 there will be 12 billion tons of plastic in landfills, the equivalent of 35,000 Empire State Buildings weight [5]. However, it is also important to underline the functional features and benefits of packaging that have the fundamental function to protect the product from environmental aggressions [3,4]. Additionally, further innovations in product containers and packaging materials are expected by consumers afraid of the contamination risk because of the COVID-19 pandemic [6,7]. This aggressive virus, in fact, "has challenged beauty markets like never before, "disrupting the normal beauty usage habits, engagement and sales," exacerbating stress and anxiety levels also [8]. Thus, innovations have been focused to study and make innovative beauty masks easy and comfortable for helping consumers at home to re-engage their selves with stressing transfer-proof beauty product formulations [8-10].

The new biodegradable beauty mask helps to maintain healthy skin, avoiding the inflammation cascade provoked by the continuous use of surgical face masks, also acting as a stress transferring proof formulation [8]. In any way, together with the booming of USD 500 billion/year of the global care industry, the global cosmetic packaging market, $40 \%$ of which is used just once, is projected to attain a share of more than USD 35 billion by 2023 and is expected to expand at a compound annual growth rate (CAGR) of $5.2 \%$ from the year 2018 to 2023 [7,8]. However, during the COVID-19 pandemic, emerging markets such as Indonesia $(+12.9 \%)$, Turkey $(+11.9 \%)$, India $(+7.3 \%)$, Vietnam $(+6.8 \%)$, and 
Russia $(+6.2 \%)$ have shown a growth of their retail market for shampoos and conditioners, while EU Countries such as, for example, France $(-1.7 \%)$, UK $(-1.1 \%)$, Sweden $(0.8 \%)$, Germany $(-0.6 \%)$ and Norway $(-0.5 \%)$ reduced their consumption [2]. Unfortunately, the containers' plastic segment is expected to gain a major market shear because of its convenient and hygienic qualities, low cost, lightness, and versatility. Thus, the necessity to replace the plastic polymers with biopolymers to reduce the carbon footprint [11]. The APAC cosmetic packaging market, especially in India, China, and Indonesia, is expected to grow at a higher pace during the forecast period 2018-2023, owing to the rising consumer preference for eco-friendly products and increasing demand for small-sized packaging. Anti-aging products and e-commerce are further pushing the market growth together with the request for luxury products [12]. The necessity to reduce waste, produce and consume cosmetics, beauty- and surgical masks, textiles, and other goods made by biodegradable polymers has become an urgent necessity. This new way of living could certainly save human health and the environment, hoping that the COVID-19 pandemic may act as a catalyst in the implementation of the circular economy at full capacity [13-15].

\section{Waste, Climate Changing, and Wellbeing}

The Earth's climate has rapidly changed during the last 200 years after more than 10,000 years of relative stability $[16,17]$. This sudden change is provoking rising temperatures and environmental disasters, with a consequential socio-economic impact on the livability of flora, fauna, and human kind, as well as on the workability, food systems, physical assets, infrastructure services, and natural capital of our planet $[16,17]$. The principal problem is due to the current linear economy which, fundamentally based on "take, consume and waste", in 2019 caused a record emission into the atmosphere of 36.8 billion tonnes of $\mathrm{CO}_{2}$, according to the Global Carbon Project. [18]. However, it is not wise to forget the greenhouse gas (GHG) emissions of methane, which represent the second largest contribution to human-caused global warming after carbon dioxide (Figure 2) [19]. From 2017, its emission was around 9\% higher than 2000-2006, reaching in the atmosphere around 1875 part per billion, more than two-and-a-half times pre-industrial levels. Anyway, the dominant cause of this global increase is principally due to agriculture, cattle farming, waste sector, fossil fuel use, and manufacturing processes.

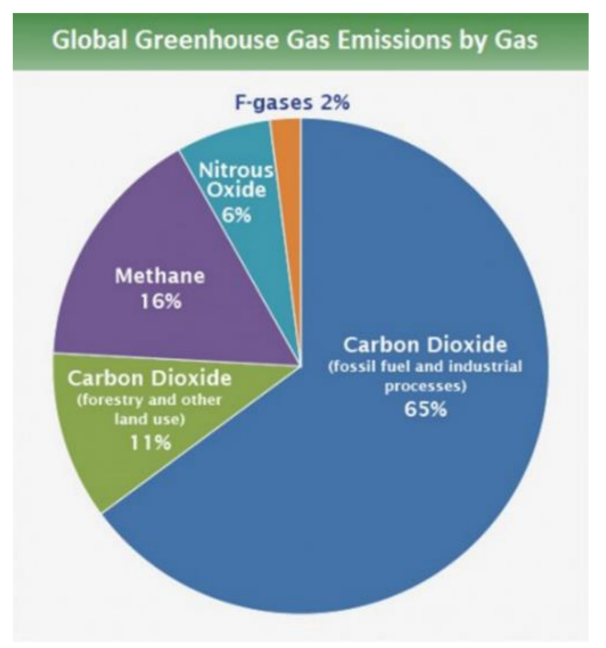

Figure 2. Worldwide greenhouse gas emissions in 2018: Different contribution (by courtesy of EPA [19]).

Among the great quantity of waste, in fact, the production and use of plastics represent another great problem to face, because of its non-biodegradability. In 2019, in fact, the production and incineration of plastic added more than 850 million metrics tons of greenhouse gas (GHG) to the atmosphere, with a global demand estimated to increase by $22 \%$ over the 
next five years, while their GHG emissions will reach $17 \%$ of the global emission of carbon dioxide by 2050 [20]. It is important to remember that plastics, coming from petrol, have carbon-intense life cycles, represented by their extraction and distillation, production of polymers and goods with the relative consumption of energy, all processes that emit GHGs. Unfortunately, while EU mindful consumers and politicians are promoting the reduction of single-use plastics, dreaming of a plastic-free world, some manufacturers are creating new plastic packaging to replace traditional paper uses such as plastic teabags or coffee-cups. Just to give an idea, 400 billion coffee-cups are consumed every year worldwide, while only one per cent are recycled [21]! Thus, the necessity to reduce, re-use, and recycle all waste material, for building new value-chains and sustainable processes, must be considered pivotal in our society.

Regarding the non-biodegradable materials, in fact, it is to underline that, because of the global plastic-waste volumes estimated to grow from 260 million tons per year in 2016 to 460 million by 2030, its reuse could become an important driver of profitability for chemical industries, also saving the environment from the actual disasters [22]. Additionally, it is to underline that today the decision to purchase is coming from the habits and consumers lives versus a clean environment and the attitudes to maintain a beauty appearance with a healthy body [23]. Thus, all consumers from different generations, from Generation $Z$ (aged 18-22), Millennials (aged 18-34), and Baby Boomers (aged 55-73) are looking at health with a more holistic approach of reducing stress, spending more time on themselves to live a more balanced lifestyle, underpinned by convenience, transparency, and value [23-26].

As a consequence, consumers make investments in high-quality, high-performing, natural-oriented, and plastic-free products, seeking physical and mental wellbeing with a safe environment with clean air and water [26]. Body health and mental wellbeing, in fact, "are considered a key factor in perception of health and stress by $65 \%$ of global consumers", while "34\% take measures to manage anxiety and mental health" [25], increased ultimately for the COVID-19 pandemic, which is causing moderate to high or extreme stress levels [27]. However, Millennials are the largest potential buying group who, showing preferences in beauty and personal care products, accounts for about $32 \%$ of the world population, compared to $17 \%$ for those over 55 years old (baby boomer and older).

Thus, regarding the market, it is to be remembered that actual global sales of beauty and personal products are evaluated at USD 500 billion and expected to reach USD 800 billion by 2023, with a forecast annual growth rate of over $7 \%[24,28]$.

In conclusion, physical and psychological stress, together with an unfavorable environment, affect the human wellbeing of the body, in particular the skin, where puffy eyes, dark circles, sagging, and wrinkles are appearing. Moreover, the hair fibers undergo some degree of cuticular and secondary cortical breakdown from root to tip, due not only to the aging phenomena, but also to the too frequent brushing and cosmetic procedures, such as permanent waving and bleaching, that enhance this process. Regarding hair wellbeing, the reason to use chitin nanofibrils and nanolignin is the main topic of this paper, which reports some literature results, focusing the discussion on their supposed mechanism of action on the hair structure. These biodegradable polymers could be used both as carriers and active ingredients for the treatment of hair damaged by stress, aging, and the environmental weathering processes, introducing the new concept of cosmeceutical-tissues [29], as previously proposed for the skin [14].

\section{The Hair}

Biologically, human hair is a particular complex of fibers, consisting of various morphological components, including the outside cuticle, the inside cortex, and the central medulla, all bound by the cell membrane cortex (Figure 3). It consists of hardened dead cells, prevalently made of keratins which, as fibrous proteins, contain $18 \%$ of cysteine, produced by the same mechanism used from the skin corneocytes. However, both corneocytes and the hair' cells are continually produced, decay, and die during all of the life period. During the decay process, cells stock a great quantity of keratins, therefore representing the 
main component of the skin' stratum corneum, hair, and nail, also if in different quantities. Without entering into the merit of the specific keratins' composition, it is important to consider the hair as a specialized organ inserted into the skin since its birth formation. It represents the final part of the keratinization' process that starts at the level of the bulb's proliferative region of the follicle from where it is produced (Figure 3) [30].

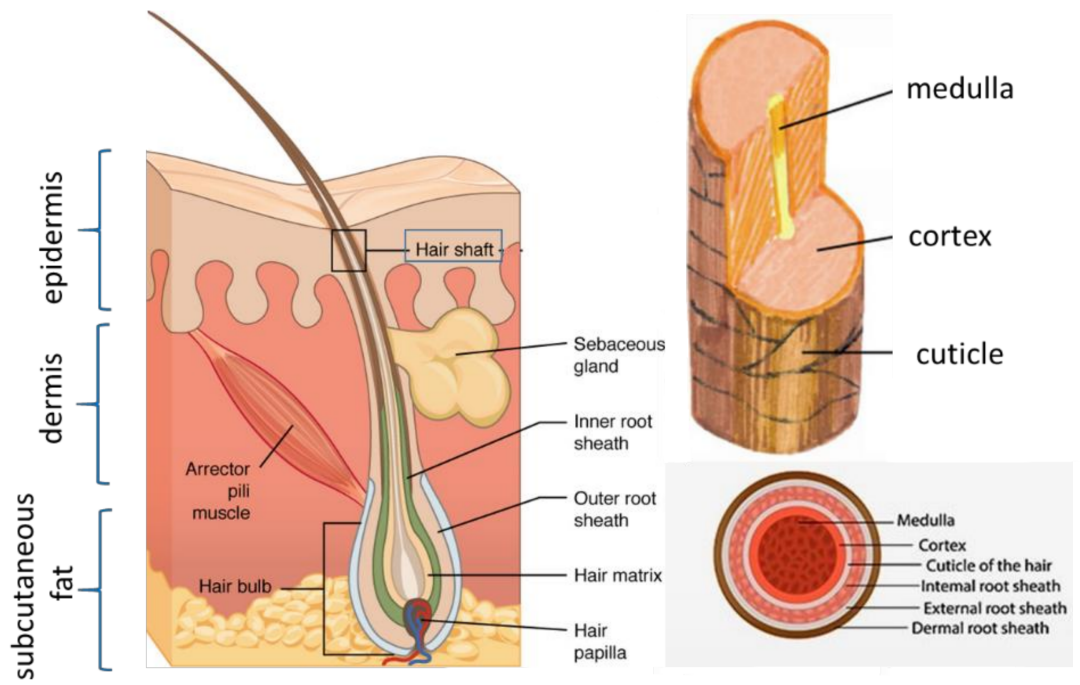

Figure 3. The structure of hair integrated in the skin.

Sebaceous glands, which produce sebum, necessary for the hair brightness and flexibility, are located in the upper part of follicle, while the papilla necessary for the hair nourishment is located in the lower part, distributed through the blood stream system. Additionally, it is important to remember the arrector pili muscle, that, consisting of a small band of smooth muscle, connects the hair follicle to the tissue of the basement membrane. It has the important role to develop and maintain the integrity and stability of the pilosebaceous unit [31].

As previously pointed out, both human and animal hair are composed of outer protective thin layers of a cell-sheath covered by scales, jointly by different keratin fibers and organized as a plain-tiles roof (Figure 1), named cuticle. The cuticle consists of a series of flattened cells wrapped around its cortical core which, named cortex, constitutes its basic elastic structure. All these cells, which contain various sub cellular layers of keratins, cross-linked mainly by the amino acid cysteine, result in important structural stability for the hair, acting also as a hair's barrier to the penetration of any kind of ingredient. Sebum, produced from the sebaceous gland, has the function to further protect the hair, giving it brightness and facility to comb also, as previously focused on.

In conclusion, hair consists of a cylinder structure with a central core of longitudinally oriented and tightly packed spindle-shaped cortical cells, sheathed by highly keratinized cells overlapped each other from root to tip along the fiber (Figure 1a). The outer scales provide a superficially imbricate cuticular structure which, by the help of sebum, results as a necessary protective layer against environmental degenerative forces, such as friction, pulling, and ultraviolet (UV) radiation.

It is interesting to know that sebum, covering the hair surface as an efficient lubricant, is composed of fatty acids covalently linked to the keratin structure, 50 percent of which is represented by 18-methyl eicosanoic acid (18-MEA) bound as a thio-ester or as an oxygen ester $[30,32,33]$.

Regarding the chemical composition, hair comprises up to 95\% keratins, high molecular weight proteins, made medially by 18-23 different amino acids (AA). The fibers of these specialized proteins are coiled together in an organized chain-fashion of AA bonded together in a specific sequence to form alpha-helix structures, which include dimers, 
protofibrils, microfibrils, and macrofibrils, stabilized by inter-macromolecular hydrogen bonds (Figure 4a) [34].

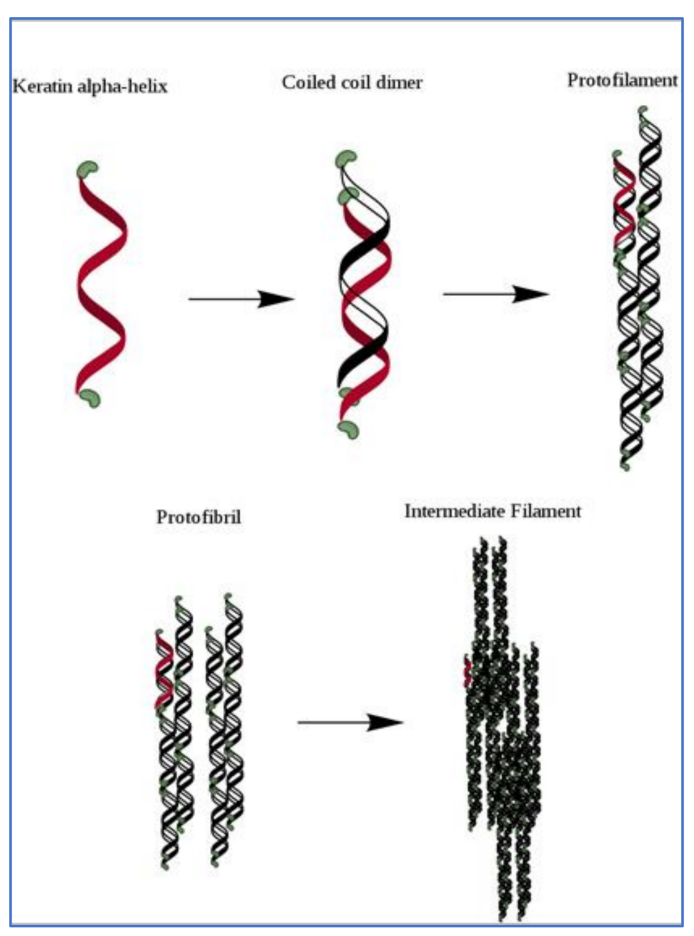

(a)

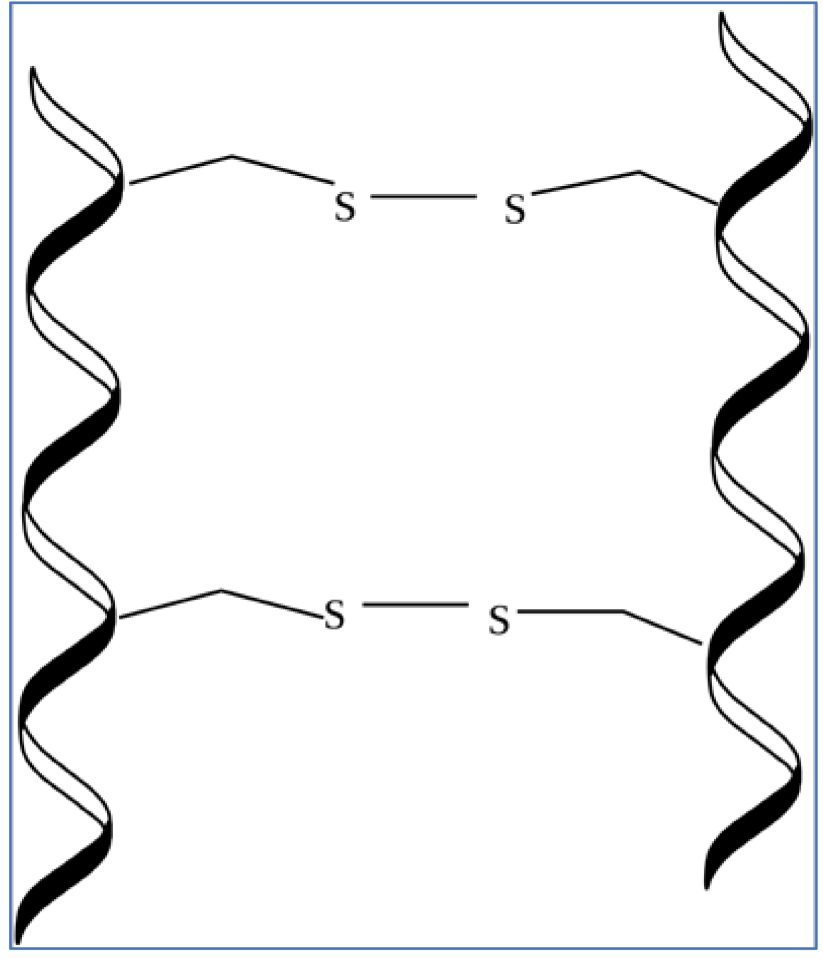

(b)

Figure 4. Structure of proteins of the hair: (a) The alpha-helix molecular sub-structure of the hair made by a macrofibrillar/microfibrillar coiled structure (by the courtesy of Wikipedia); (b) the inter-chains S-bond between the amino acid cystine (by the courtesy of Wikipedia).

Three alpha-helices are twisted together to form protofibrils, while nine protofibrils are bundled up to form hundreds of microfibrils embedded in matrix proteins. Thus, nanofibrils (i.e., alpha-helices) are connected to form microfibrils by intramolecular hydrogen bonds, linking the carbonyl group of one amino acid to the amino group of another amino acid. Moreover, it isn't wise to forget the so-called S-Bond (Figure 4b) which, formed between cystine amino acid of the main polypeptide chain, plays a fundamental role, being responsible for the hair's strength and resistance to abrasion. This cystine bond, therefore, is essential to change hair appearance during some cosmetic treatments.

Going back to the AA forming the keratin polypeptides, they may be subdivided in monoamine, such as alanine (28-35\%), valine $(5.0-5.8 \%)$, leucine $(6.4-6.9 \%)$, glycine $(5.2-6.1 \%)$, isoleucine $(2.3-2.5 \%)$, serine $(9.6-10.8 \%)$, and threonine $(6.5-7.5 \%)$, defined as acyclic compounds; aromatic compounds such as phenylalanine(2.2-2.8\%), tyrosine $(2.1-2.7 \%)$, and tryptophane $(0.8-1.2 \%)$, and cyclic compounds like proline $(7.0-7.8 \%)$; monoamine diacids, such as heterocyclic compounds like aspartic acid (5.6-6.5\%) and glutamic acid (14.3-15.5\%); monoacid diamines, such as Lysine (2.6-3.1\%), arginine (8.8-9.6\%), and histidine (8-11\%), and sulfur-containing compounds, such as Cysteine (14.0-16.5\%) and methionine $(0.5-0.9 \%)$ [35].

However, all these amino acids are molecules characterized by different polarities, so that alanine, leucine, valine, isoleucine, proline, methionine, cysteine, and phenylalanine are hydrophobic and non-polar; serine, threonine, tyrosine, and glycine are polar compounds which, characterized for their electrical neutrality, have the possibility to form hydrogen bonds with water and among each other. On the other hand, lysine, arginine, 
and histidine are positively charged in slightly acidic solutions, while glutamic acid and aspartic acid are partially negatively charged because of acid dissociation.

In conclusion, the hair is fundamentally formed by macrofibrils of keratin made by polypeptides arranged longitudinally within each cortical cell and packed together with an inter-macrofibrillar amorphous matrix of keratin associated proteins. Thus, when keratin is arranged in its wrapped alpha-form, hair possesses "cohesion provided by net-works, such as catenated cystine cross-linkages, interactions between side chain groups, hydrogen bonds between neighboring groups, and hydrophobic interactions" [35]. In fact, "although hydrogen bonds are rather weak because of their lower energy when compared with covalent bonds, a high number of inter-peptide bonds can initiate substantial changes to the mechanical behaviour of single and dense hair fibril systems" [36]. However, when keratin is in its beta-form, hair is stretched. Thus, the possibility to change its packed structure, passing from alpha- to the beta form, gives the hair the tensile properties used, for example, to formulate different cosmetic products, such as hair setting or permanent waving. These treatments, based on the modification or/and reduction of the keratin bonds, are able to change the hair structure by a strengthening of the hair's fibers mechanical properties. Therefore, a deep knowledge regarding the hair' materials structure, with their hierarchical structure and relative physicochemical properties, is fundamental to understand the response to the routine grooming and cosmetic treatments [37].

Naturally, the hair's cosmetic products have to be focused and formulated differently, in dependence of their designed activity, strictly connected with the hair fibers condition, the amino acid composition, and their inter-chain hydrogen bonds [38]. Thus, the rupture of ionic linkages or hydrogen bonds that leads to temporary hair deformation is used for the hair setting, while the cleavage of cystine links and their reforming in a new position is the process used for permanent deformation [39].

A part of the treatments that can temporarily or permanently modify the hair structure, both hair and skin have to be continually cleaned to eliminate the excessive dirt and greasy materials from their surface, possibly maintaining both structure and the physiological lubricant compounds. This is the action, for example, of any shampoo that should only act on both scalp and the hair' fibers, at the level of its cuticle scales, activating and absorbing the selected ingredients [1]. On the other hand, the so-called conditioners have to maintain manageability, softness, and flexibility of the hair structure, directly acting on its fibers at the level of cortex [1]. As previously reported, this activity is particularly important to repair hair damaged for an excessive combing or for the negative chemical activity of setting and permanent waving, which involve the breaking and restructuring of the disulfide bonds within the hair [39,40]. Permanent waving, in fact, is the process of converting straight hair into curled ones by a chemical process involving the disulfide bonds modification $[1,39]$. However, for having the possibility to ameliorate and repair a hair's damaged structure, it is necessary to better understand not only the amino acidic sequence, but also the different bonds linking them each to others [40,41]. Some polymeric polysaccharides, such as chitin and its derived compounds, seem particularly useful at this purpose [30].

\section{Chitin and Its Derived Compounds}

In nature, chitin exists as a composite polymer consisting of $N$-acetyl-2-amido-2-deoxyD-glucose units ordered in crystalline microfibrils embedded in a matrix of protein and minerals [42]. The polymer represents an important structural component of cell walls in fungi and yeasts, as well as in exoskeletons of insects and crustaceans. For their similar composition to hyaluronic acid and their hydrophilic nature, the hair microfibrils are generally highly hydrated and therefore useful to maintain its soft and elastic structure [42]. The microfibers, in fact, swell in contact with any liquid, due to the diffusion and adsorption, for example, of water into their inter-spaces. Thus, the hair keratins, treated by a lotion or a tissue based on the use of chitin or chitin-derived compounds, seem able to adsorb up to $40 \%$ of their own weight in water, also retaining the right quantity of sebum, 
thus better reflecting the light and resulting in being more flexible in comparison with a non-treated ones. Therefore, these oligosaccharides could find use in hair cosmetics and in many other applications due to their non-toxicity, renewability, biological and environment compatibility, and antimicrobial and antioxidant effectiveness [43]. For all these reasons, around 20 million of tons of crabs, shrimps, and lobsters' exoskeleton waste are processed every year worldwide to produce chitin and derived compounds $[44,45]$. The potentialities of chitin nanofibrils and chitosan were investigated and highlighted up to now in cosmetics [9], personal care [10], and packaging applications [46], however the full chain, considering both sources management and successive processes, requires it to be better developed at an industrial level. For this main reason, these materials are not yet exploited in commercial products.

Just for trying to better understand the possible activity of chitin at the level of a damaged hair, it is interesting to compare the fibrillar organization of chitin and keratin in hair cortex, respectively (Figure 5a) [30]. Thus, chitin nanofibrils, as the main constituting polymer for a cosmetic gel or a specialized smart tissue, could substitute the damaged hair fibrils, establishing bonds with some keratin peptides, and also helping the activity of the so-called arrector pili muscle [41]. As previously reported, in fact, each hair is attached by a tiny muscle at the base of its follicle located in the dermal tissue, and this muscle seems to have a similar organization and structure of the chitin nanofibrils (Figure 5b) $[47,48]$.

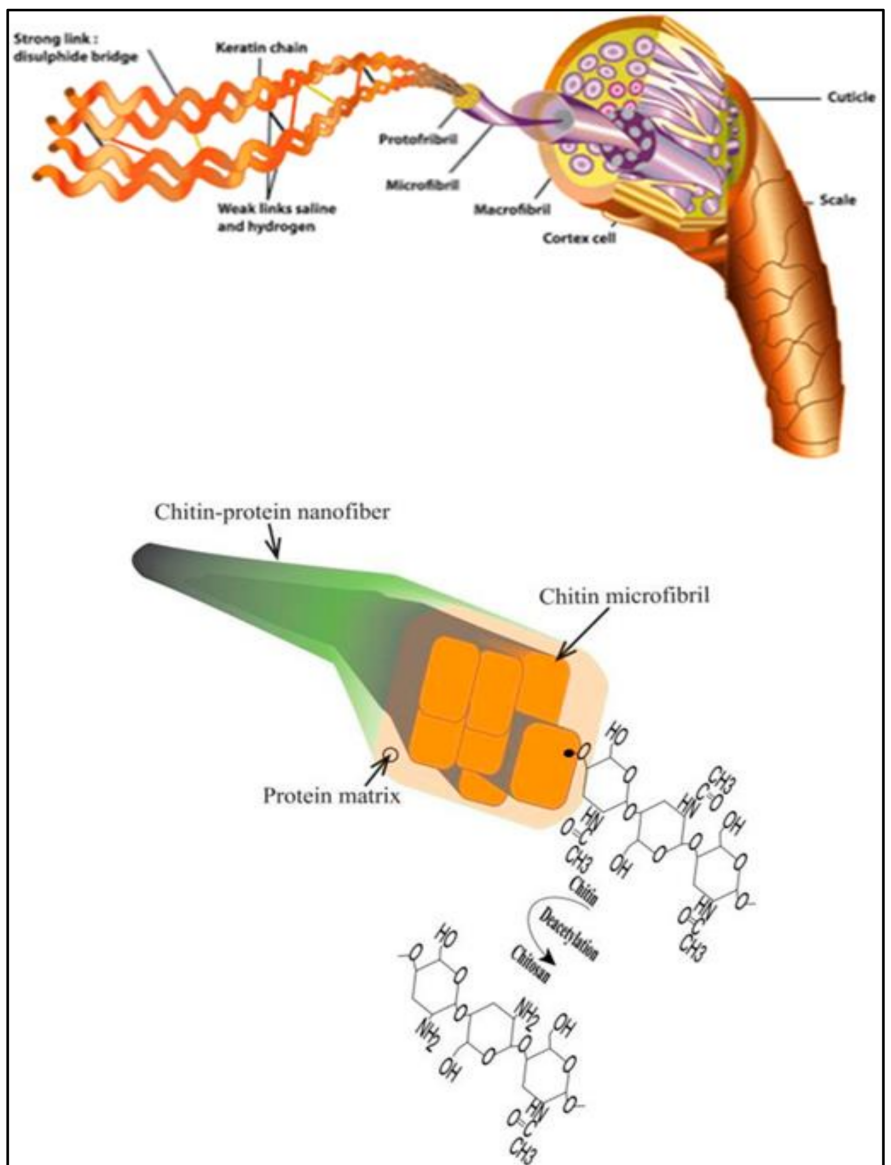

(a)

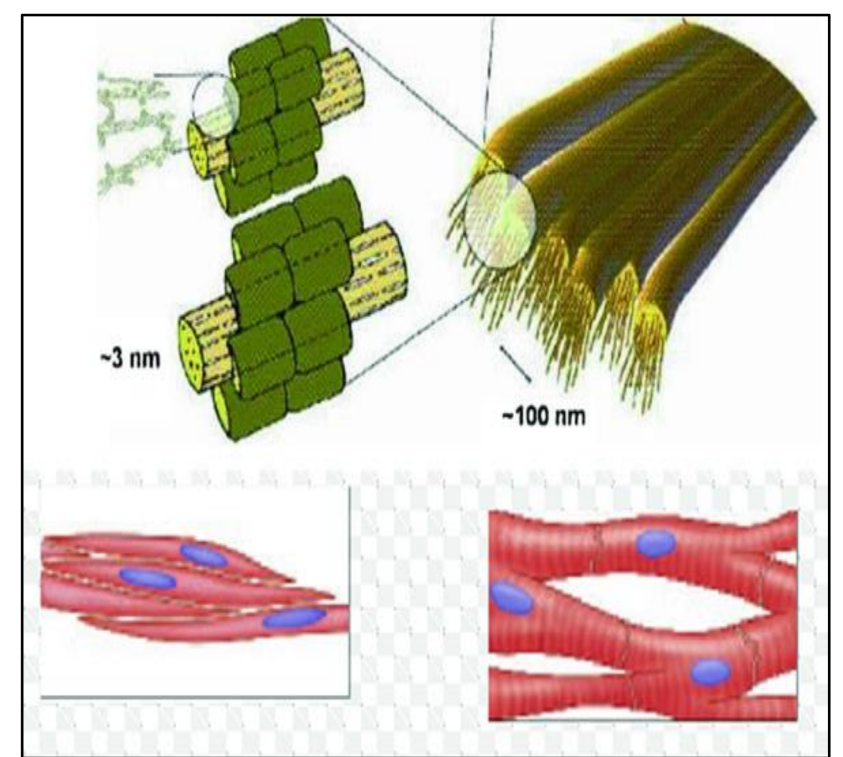

(b)

Figure 5. Similarities in biomaterial structures: (a) Hair keratin and chitin have a similar structure organization; (b) structure of chitin and muscle.

However, the global structural organization of skin and hair's keratin fibril seems to play a wider role as responsible for cell scaffolding as well as stabilizing agent against 
physical stressors, also of the mechanism by which a muscle is able to contract, repair, and regenerate its fibers, is poorly understood until today, especially for the hair [47,48].

At this purpose, it is to underline as the skin, damaged from a wound or a burn, has a self-repairing re-epithelialization mechanism which, by the three phases of inflammation, tissue formation, and tissue remodeling, is based on the production of collagen- and cellular-fibronectin-rich matrix. Thus, during the early phases of the wound repairing process, the skin's granulation tissue expansion starts to form a collagen fibers-rich tissue, through the increased production of stem cells, necessary to replace the keratinocytes lost [49]. On the other hand, the hair seems to have not the possibility to form and repair its damaged fibers by its own organization. However, as reported elsewhere from our research group also, the stem cells of the hair follicle's bulge may be activated upon fullthickness wounding, producing new inter-follicular fibers [34]. Hair, in fact, is made up of $95 \%$ keratin, synthesized in the matrix region of the bulb by proliferation and differentiation of keratinocytes which produce medulla, cortex, cuticle, and the layers of the inner root sheath [35].

Moreover, it has been shown that the outer root sheath can contribute both to the follicle matrix' regeneration, as well as to the replacement of skin epidermis, in response to wounding $[50,51]$.

In conclusion, if the hair self-repairing mechanism could be a possible existing reality, this function has not been recovered until now. The hair functions, in fact, depend on a variety of structural characteristics and repairing mechanical properties interacting at different levels, but are difficult to establish. An example could be the hydrogen and covalent sulfur bonds which differ between soft and hard keratin, characterizing skin and hair, respectively [52]. This large amount of sulfur containing cysteine, in fact, confers further additional strength and rigidity to its structure which, differently from the skin, forms inter- fibrillar disulfide bridges [52]. In conclusion, while skin has the ability to selfrepair its wounds, hair seems unable to self-restore the split ends to its original state, also if some improbable immune reply was recently reported by the use of the so called im- munecosmeceutical products [53]. Thus, in the cosmetic field, many "natural-inspired ideas" and self-repairing and fiber-reinforced biomimetic materials have been proposed [38]. These skin [29] and hair [38] new treatments, based on the use of bio-nanotechnology, innovative carriers, and natural ingredients obtained from waste, are useful to reduce the consumption of natural raw materials and save the environment.

\section{Chitin Nanofibril-Nano-Lignin Complexes}

By the ionotropic gelation method, chitin nanofibril-nano-lignin (CN-LG) complexes have been realized in water solution by our research group, utilizing the attractive forces existing, for example, between the chitin polymer positively charged and the nano-lignin or hyaluronic acid negatively charged, to obtain micro/nanoparticles (NPs) (Figure 6) [54-56]. Thus, it has been possible to make many different CN-LG nanoparticles, encapsulating different active ingredients such as glycyrrhetinic acid, etc. [57]. The various nanoparticles, obtained in powder by the spray drier method, have been bound to the fibers for characterizing the activity of non-woven-tissues, made by electro-spinning technology. Therefore, an advanced biodegradable tissue has been produced characterized by the antioxidant, immunomodulant, antibacterial, and skin repairing activities of both chitin and lignin, reinforced by the antimicrobial activity of the encapsulated silver (Figure 6) [58-61]. By this technology, it is possible to produce different tissues characterized, for example, by anti-dandruff, hair repairing, UV-screen protective activities, and/or other required functions. Naturally for our research studies, a specific nano-lignin molecule has been selected as the polymer to be complexed by chitin, being safe and effective as antioxidant and UV screening agent [62]. At this purpose, after the selection of the production' source of both chitin and lignin, it has been possible to process the polymers to obtain their nano size dimension, at high purity grade, necessary for increasing both their surface/weight ratio and effectiveness. 


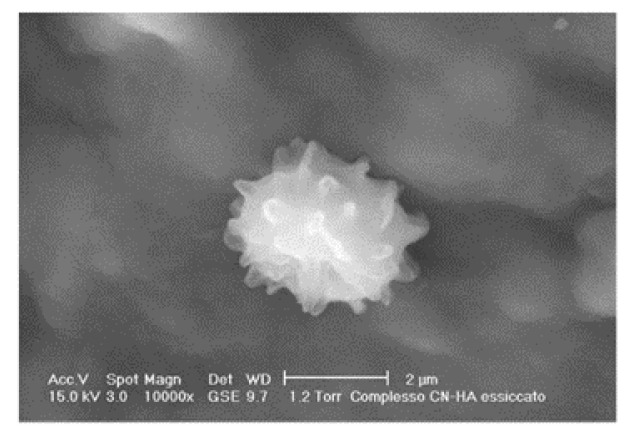

(a)

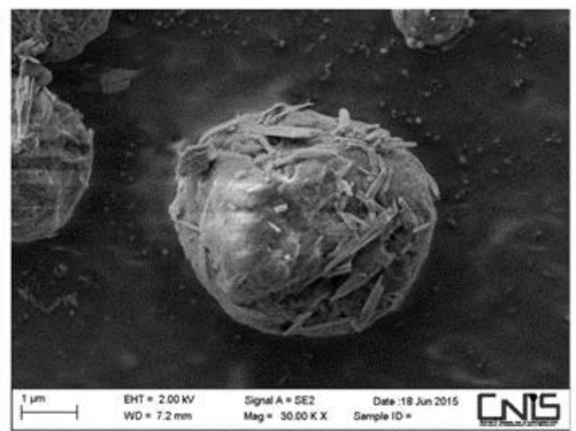

(b)

Figure 6. Chitin nanofibrils complexes: (a) Chitin Nanofibril-hyaluronic acid complex; (b) chitin nanofibril-Nano-lignin complex.

The obtained CN-LG complexed nanoparticles, bound to the fibers of water-soluble tissues and directly applied on wet hair, might release the active ingredient at dose and time deigned and at the level of both scalp and hair, by a simple soft massage. On the other hand, by the use of selected water-insoluble polymers, it may be possible to realize water-insoluble tissues (Figure 7) to be applied on the wet hair for a longer time, useful for increasing the scalp perspiration insensibility and obtaining a longer time-release of the active ingredients. Hence, these complexes can be transformed into hair products both in a liquid version (suspension) or as dry nanostructured tissues.

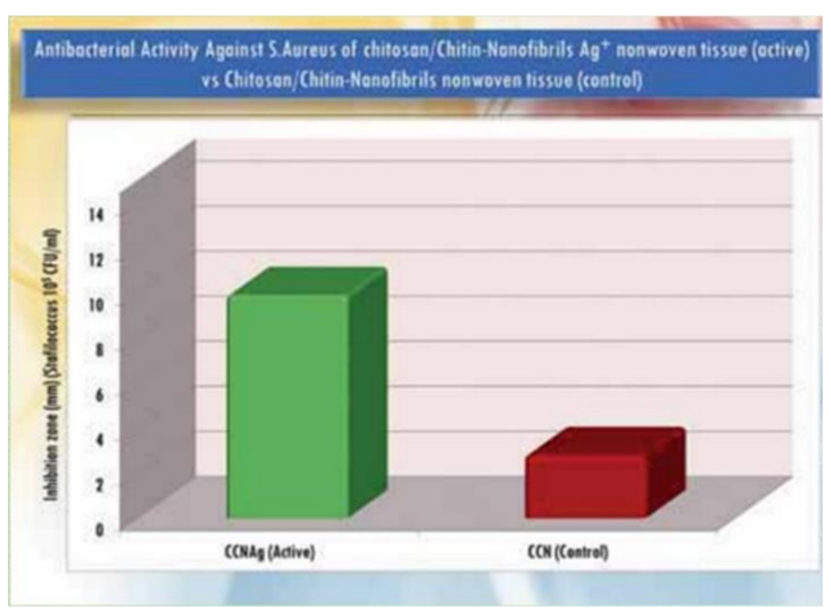

(a)

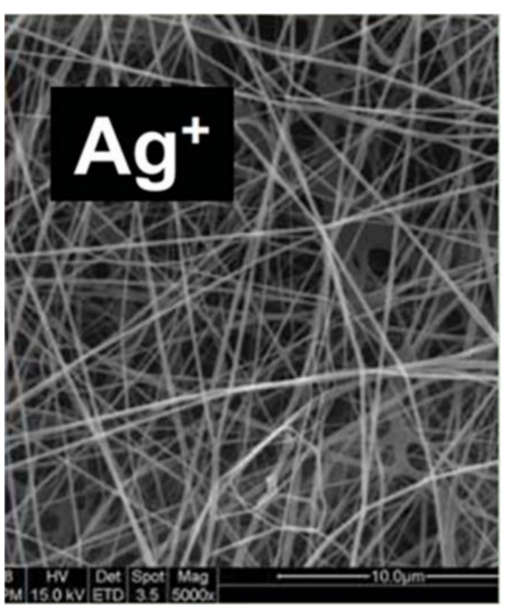

(b)

Figure 7. (a) Antibacterial activity of a Chitin-tissue the fiber of which were bound to nanostructured silver ions [63]; (b) Morphology by Scanning Electron Microscopy of nanostructured chitin-tissue [63].

By the use of these new carrier-cosmeceuticals, both active carriers and the ingredients encapsulated into CN-LG could penetrate through the scalp and hair cuticles to obtain the designed effectiveness. It is to underline, in fact, that the human enzymes have the possibility to metabolize chitin into its components such as glucosamine, acetyl-glucosamine, and glucose, as well as lignin into its polyphenolic compounds to be used from scalp cells and hair fibers as repairing agents.

On the wet scalp and by dissociation phenomena, it can occur that negatively charged lignin nanoparticles, interacting with both positively charged keratin amino acids and chitin nanofibrils, could form a film acting as repairing layers of damaged hair at the cortex level (longitudinal or end splits) (Figure 8). Moreover, chitin nanofibrils and hair proteins' amidic groups show the same chemical behavior, such as formation of intermacromolecular hydrogen bonds and other interactions, also if keratin filaments undergo 
complex regulation, involving interaction with various classes of proteins, which, until now, was not well known [51].

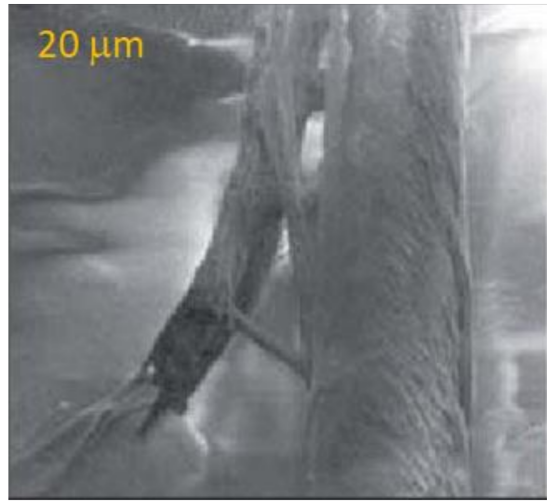

(a)

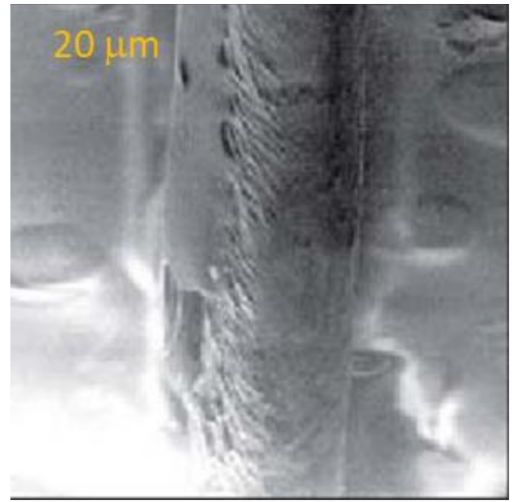

(b)

Figure 8. Microscopy image of a damaged hair. (a) Damaged hair before treatment by a chitin Nanofibril emulsion. (b) Damaged hair after treatment by a chitin Nanofibril emulsion. A representative single hair is reported.

However, as it is possible to see from Figure 8, a single damaged hair, pretreated by a $\mathrm{CN}$ suspension, has shown to be repaired at the level of the microfibrils.

At the moment, for better understanding the mechanism of action of this interesting natural polymer, we are verifying the probable relative bonds established between hair and $\mathrm{CN}$ fibrils, and also trying to determine their specific physicochemical nature [64]. They, for example, could interfere, affect, or regulate the keratin synthesis which, during the aging glycosylation process (Figure 9) and through the acetyl-glucosamine content of chitin, could modulate the hair filaments' organization, adhesion and differentiation, modified from the environmental aggressions. Probably CN-glucosamine and CN-acetyl glucosamine could be used as a brick to reinforce the hair structure by links established with keratin. Consequently, the hair fibers' tensile and elongation properties could be enhanced by the same mechanism of linkage between sugar and protein compounds recovered during the glycation process (Figure 9).

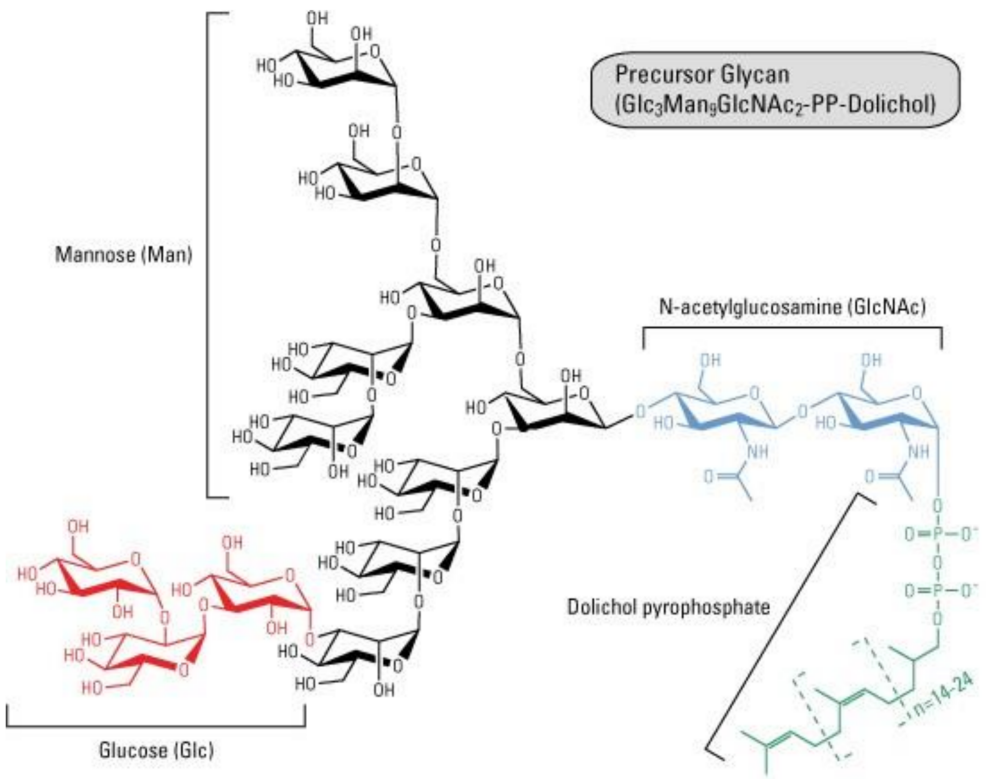

Figure 9. The acetyl-glucosamine as part of the chitin polymer may act as a hair repairing agent through the glycosylation process [64]. 
At the moment, it is to underline that $\mathrm{CN}$ has shown an interesting skin anti-inflammatory and repairing activity, probably for the likeness of its fibers to the skin soft-keratin's fibrils, also due to their micro/nano dimension. As shown from other authors, in fact, chitin could have an anti-inflammatory or pro-inflammatory effectiveness depending to its size and the fibril structural organization $[63,64]$. Consequently, it is possible to suppose that chitin nanofibrils could have the same reparative activity on the hair structure, acting probably on the crosslinked hard keratin filaments network, by the same mechanism they are using at the level of the skin soft keratin ones, as previously reported.

\section{Environmentally Friendly Packaging for Hair Products}

For hair products, rigid or flexible packaging can be used, as a function of physicalchemical properties of the specific product. The rigid packaging generally is represented by bottles, or pots and caps. Currently, the most used polymers are high density poly(ethylene) (HDPE); poly(propylene) (PP), and poly (ethylene terephthalate) (PET). This rigid packaging is generally recovered from waste and then separated from other plastics. In several countries, the fractions consisting of HDPE and PP, and PET, are obtained in plastic recycling plants. The packages are then ground into scraps, washed, and successively used in recycled products production [65].

Flexible packaging, currently made with Low Density Poly(ethylene), PP, and PET, can consist of a single material or of a multilayer system. Multilayer packages, used for their high barrier properties, consist often not only of plastic, but also of aluminum and paper. These are usually lighter than rigid packaging items, and the weight fraction of plastic is thus lower. The percentage of contaminants consisting of residual liquid or cream products thus affects the recovery of single materials. Hence, this fraction is usually managed by incineration (or landfilling) because its recycling is not feasible (Figure 10). This life cycle is thus less sustainable than that of rigid packages, and more sustainable options should be considered as soon as possible.

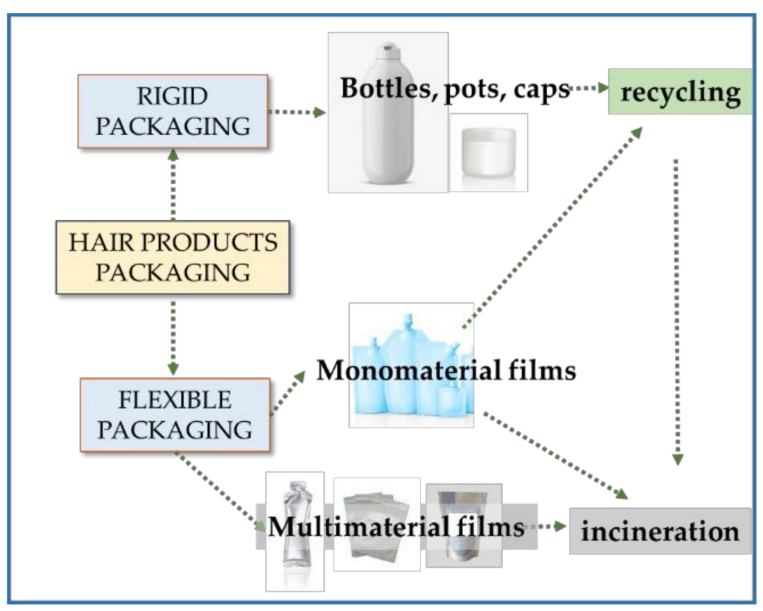

(a)

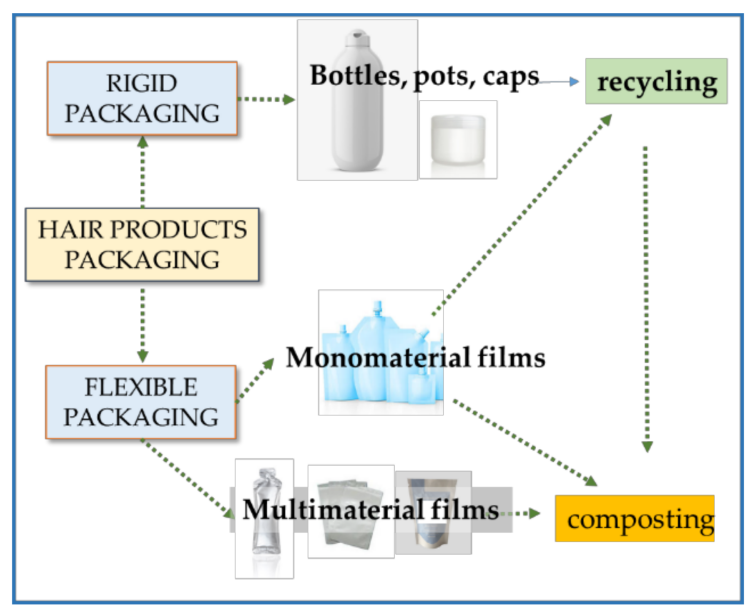

(b)

Figure 10. Classification and waste management of packaging for hair products: (a) Current fossil-based scenario; (b) scenario considering compostable bioplastics.

In the future, biodegradable plastics, like poly (lactic acid) (PLA), polyhydroxyalcanoates (PHA), other biopolyesters, and starch, will be adopted more and more in packaging applications, and their increased use is envisaged in the personal care sector [64]. If they will be used in hair products packaging, the scenario could be different. In fact, rigid packaging will be recycled, but after some life cycles, the material can be composted. As composting is now assimilated to recycling [66], the perspectives of waste management will improve with respect to the current scenario (Figure 10). Flexible packaging can be composted as well, thus solving the issue of its difficult recyclability. The possibility of com- 
posting cosmetic packages can be negatively affected by the presence of residual products, since the presence of detergents or preservatives can be detrimental for the bacteria and microorganism activity in compost, which can be limited or disabled due to the presence of such substances $[67,68]$. Hence, hair products formulations should be based on fully biodegradable substances $[69,70]$. Chitin nanofibrils and their complexes are thus perfect additives as they are fully biodegradable and not detrimental for the environment [71]. Recently, it was evidenced that a material based on protein $/ \mathrm{CaCO}_{3} /$ chitin nanofibrils is a good fertilizer to improve plant growth in hydroponic systems [72]. Moreover, Fatima et al. [73] demonstrated a good fertilizing activity for potatoes and wheat.

Interestingly, chitin nanofibrils can be dispersed by extrusion in biobased plastics like PLA $[74,75]$ or other biopolyesters [76] to obtain rigid or flexible bionanocomposites that can be used in hair product packaging. Chitin nanofibrils were demonstrated to have a slight indirect anti-microbial action if incorporated in these films [77] and to be useful in modulating the release of low molecular weight substances from bioplastic blends [78], as well as regenerative properties for skin cells. Hence, an intelligent packaging could potentially include chitin nanofibrils in its formulation, exploiting these interesting functional properties or in combination with other natural molecules [57]. In general, these bioplastic formulations are compostable, and then addressed to be converted in compost (in industrial or, in some cases, home-composting plants [79]) when they become a waste. Certainly, the final compost, incorporating chitin nanofibrils, should be potentially spread on the ground in agricultural practices to promote plants growth. These bionanocomposites, incorporating chitin nanofibrils, thus represent an advantageous opportunity for producing flexible or rigid packaging.

Chitin nanofibrils can be available as water suspension, hence they can be applied starting from a liquid product. In this case, a rigid packaging can be the best option. In the case of a dry tissue incorporating chitin nanofibrils or its complexes, it is possible the use of a packaging based on cellulose. The treatment of the inner surface of the cellulose with chitin nanofibrils will provide anti-microbial action to the packaging, as noticed by Panariello et al. [46] in cellulosic packaging for food.

\section{Conclusions}

The great plastic waste, increased by further tonnes of the non-biodegradable surgical masks and medical dressings used and in use for the COVID-19 pandemic, is generating much waste and carbon dioxide and methane emissions, along with an important socioeconomic impact from the intensified climate changing. Moreover, during the years 1950-2018, global production of plastics and synthetic polymers had a compound annual growth rate (CAGR) of $8.3 \%$ with an estimated 9200 million metric tonnes (Mt) of mini- plastics produced, $5300 \mathrm{Mt}$ of which were discarded in the environment. As a consequence, marine organisms were impacted by the uptake of toxic chemicals consumed through the human food [80]. In the same period, the global use of non-biodegradable apparel and washing machine waste resulted in total microfiber emissions ranging from 4.3 MT to 7.0 Mt with a CAGR of $12.9 \%$. According to OECD prevision, production and incineration of plastics and synthetic fibers will add more than one million metric tons of GHG emissions in the atmosphere, while countries worldwide could lose around USD 10 trillion in cumulative GDP by 2024 [81-83]. Thus, the necessity to use the tremendous potential of scientific progress, technology, and innovation in polymeric science for making a new class of natural and smart hair cosmetics and packaging by the use of these biodegradable polymers and tissues.

As for cosmeceutical-tissues proposed for the skin [29,84], it seems possible to produce a products' tissue-line for hair also, to protect both hair and scalp from environment and some aggressive cosmetic treatments, possibly inducing a self-repairing activity of their structure as well. These smart and innovative tissues, containing active ingredients directly bound to their fibers and made by natural biodegradable polymers, seem to be not only effective for the activity of both the natural carriers and ingredients used, but also charac- 
terized for their safeness and effectiveness because free of preservatives, emulsifiers, colors, fragrances, and any other kind of chemicals. They, in fact, are produced and packaged at the dry state and are therefore free of water, fundamental for the microorganism's growth The scaling up of these tissues from the lab-production is the actual goal of our research group, to try to slow down or eliminate waste in this specialized cosmetic sector, realizing innovative hair- and skin environmentally-friendly products. These dry tissues, as well as other versions, for instance water suspensions, can be packed in sustainable packaging based on a cellulose surface treated with chitin nanofibrils (in the case of dry solids) or in bioplastics incorporating chitin nanofibrils (in the case of wet solids or liquids). New smart and sustainable hair products could benefit from these findings regarding the valorization of high-value waste, offering to green-minded consumers diversified options for their personal care and health.

Author Contributions: Conceptualization P.M.; writing original—draft preparation P.M. and M.-B.C.; writing review and addicting P.M., M.-B.C., G.M.; supervision P.M., M.-B.C. All authors have read and agreed to the published version of the manuscript.

Funding: This research received no external funding.

Institutional Review Board Statement: Not applicable.

Informed Consent Statement: Not applicable.

Conflicts of Interest: The authors declare no conflict of interest.

\section{References}

1. Reis Gavazzoni Dias, M.F. Hair cosmetics: An overview. Int. J. Trichol. 2015, 7, 2-15. [CrossRef] [PubMed]

2. McDougall, A. What's Next in Hair Care: Emerging Trends. 2019, Mintel Report, UK. Available online: www.mintel.com (accessed on 5 March 2021).

3. Amberg, N.; Fogarassy, C. Green consumer behaviours in the cosmetic market. Resources 2019, 8, 137. [CrossRef]

4. Cosmetic Europe. Environmental Sustainability. The Cosmetic Industry's Contribution 2017-2019; Cosmetic Europe: Brussels, Belgium, 2019.

5. UNEP. Plastic in Cosmetics; United Nation of Environmental Program: Amsterdam, The Netherlands, 2015.

6. Fever, D.; Lingvist, O.; Nordigarden, D. How the Packaging Industry Can Navigate the Coronavirus Pandemic. 2020 McKinsey \& Company Report. Available online: www.mckinsey.com (accessed on 5 March 2021).

7. MRS. Market Key Insight and COVID-19 Impact Analysis, 2020. Market Research Future Report. Available online: www. marketresearchfuture.com (accessed on 19 November 2020).

8. Di Gesu, R. 6 Ways COVID-19 Spurred on Creative Beauty/Personal Care. 2020, Mintel Report. Available online: www.mintel.com (accessed on 19 November 2020).

9. Coltelli, M.B.; Panariello, L.; Morganti, P.; Danti, S.; Baroni, A.; Lazzeri, A.; Fusco, A.; Donnarumma, G. Skin compatible biobased beauty masks prepared by extrusion. J. Funct. Biomater. 2020, 11, 23. [CrossRef]

10. Morganti, P.; Yudin, V.E.; Morganti, G.; Coltelli, M.B. Trends in surgical and beauty masks for a cleaner environment. Cosmetics 2020, 7, 68. [CrossRef]

11. MRFR. Cosmetic Packaging Market, 2020. COVID-19 Analysis, Application, Global Size, Share, Business Strategies, Huge Demand Value, Segments, Future Scope, Trends and Forecast Period 2018-2023. Market Research Future. Available online: report.www.marketresearchfuture.com (accessed on 11 November 2020).

12. Reichert, C.L.; Bugnicourt, E.; Coltelli, M.B.; Cinelli, P.; Lazzeri, A.; Canesi, I.; Braca, F.; Nartinez, B.M.; Alonso, R.; Agostinis, L.; et al. Biobased packaging: Materials, modifications, industrial applications and sustainability. Polymers 2020, 12, 1558. [CrossRef]

13. Morganti, P.; Morganti, G. Surgical \& beauty facial masks: The new waste problem of post COVID-19. Biomed. Sci. Tech. Res. 2020. [CrossRef]

14. Morganti, P.; Morganti, G. Post-COVID-19: Opportunity to produce biodegradable goods \& surgical masks to save the environment. J. Health Care Res. 2020, 1, 157-165. [CrossRef]

15. Morganti, P.; Morganti, G. Textile \& waste: Will be COVID-19 a catalyst for changing? J. Text. Eng. Fash. Tech. 2020, 2, 26-31.

16. UN. Change of Climate Change Imprints, Climate Technology Centre E Network; United Nations Environment Program: New York, NY, USA, 2020.

17. MGI. Climate Risk and Response in Asia. 2020, The MacKinsey Global Report Institute. Available online: www.makinsey.com (accessed on 29 August 2020).

18. The Conversation. Global Emissions to Hit 36.8 Billion Tonnes, Beating Last Year's Record High. 4 December 2019. Available online: https: / theconversation.com/global-emissions-to-hit-36-8-billion-tonnes-beating-last-years-record-high-128113 (accessed on 5 March 2021). 
19. EPA. Overview of Greenhouse Gases. United States Environmental Protection Agency: Washington, DC, USA, 2020. Available online: https:/ / www.epa.gov/ghgemissions (accessed on 26 August 2020).

20. CIEL. Plastic \& Climate. The Hidden Costs of a Plastic Planet. 2019, Center for International Environmental Law (CIEL) Report. Available online: www.ciel.org/plasticaclimate (accessed on 26 August 2020).

21. Greyhound, P. 22,000 Coffee Cups Disposed of in Ireland Every Hour. 2019, Greyhound Recycling. Available online: www. greyhound.ie (accessed on 29 August 2020).

22. Hundertmar, K.T.; Mayer, M.; McNelly, C.; Simons, T.S.; Witte, C. How Plastics Waste Recycling Could Transform the Chemical Industry; McKinsey and Company: New York, NY, USA, 2018.

23. Shridhar, A. Health by Generation-Understanding Health Lifestyles and Behaviours. Euromonitor International Report. Available online: https:/ / go.euromonitor.com/white-paper-ch-2020-health-by-generation.html (accessed on 5 March 2021).

24. Mason, A.; Garfeld, D.; Greenway, J. Naturally Beautiful: Millennials and Preferences in Beauty and Personal care Products. 2018. Available online: www.alixpartners.com (accessed on 29 August 2020).

25. Jindal, S.; Kwek, S.; McDougall, A. Global Beauty and Personal Care Trends 2030. Mintel Report. 2020. Available online: www.mintel.com (accessed on 29 August 2020).

26. Crabbe, M.; Lieberman, G.; Moriarty, S. Consumer Trends 2030. Mintel Report. 2020. Available online: www.mintel.com (accessed on 29 August 2020).

27. Barbalova, I.; Oster, M. Health and Beauty in the Coronavirus Era. Euromonitor International Report. 2020. Available online: https:/ / go.euromonitor.com/webinar-bpc-2020-covidhealthbeauty.html (accessed on 5 March 2021).

28. Ridder, M. Cosmetics Industry -Statistics \& Facts, 2020. Statista. Available online: https://www.statista.com/topics/3137 / cosmetics-industry/ (accessed on 5 March 2021).

29. Morganti, P.; Coltelli, M.B. A new carrier for advanced cosmeceuticals. Cosmetics 2019, 6, 10. [CrossRef]

30. Riddell, J.; Johansson, J.A.; Ford, M.J.; Jahoda, C.A.B.; Klika, V.; Mort, R.L.; Headon, D.J. Hierarchical Patterning modes orchestrate hair follicle morphogenesis. PLoS Biol. 2017, 15, e2002117.

31. Narisawa, Y.; Kohda, H. Arrector pili muscles surround human facial vellus hair follicles. Br. J. Dermatol. 1993, 129, 138-139. [CrossRef]

32. Evans, D.J.; Laczki, M. Cleavage of integral surface lipids by aminolysis. Text. Res. J. 1997, 67, 435-444. [CrossRef]

33. Tabor, D. Friction as a dissipative process. In Fundamentals of Friction Macroscopic and Microscopic Processes; Singer, I.L., Pollock, H.M., Eds.; Kluwer Academic Publishers: Dordrecht, The Netherlands, 2020; pp. 3-24.

34. Yu, J.; Yu, D.; Checkla, D.M.; Freedberg, I.M.; Bertolino, A.P. Human hair keratins. J. Investig. Dermatol. 1993, 101, 56S-59S. [CrossRef]

35. Zoak, C.; Dawber, R.P.R. Hair structure, function and physicochemical properties. In The Science of Hair Care; Zviak, C., Ed.; Marcel Dekker Inc.: New York, NY, USA, 1986; pp. 1-48.

36. Benzarti, M.; Pailler-Mattei, C.; Jamart, J.; Zahouani, H. The effect of hydration in the mechanical behaviour of hair. Exp. Mech. 2014, 54, 1411-1419. [CrossRef]

37. Robles Velasco, M.V.; de Sa Dias, T.C.; de Freitas, A.Z.; Vieira Junior, N.D.; Kaneko, M.T.; Rolim Baby, A. Hair fiber characteristics and method to evaluate hair physical and mechanical properties. Braz. J. Pharm. Sci. 2009, 42, 153-162. [CrossRef]

38. Staron, P.; Banach, M.; Kowalski, Z. Keratin-origins, properties, applications. CHEMIK 2011, 65, $1019-1026$.

39. Zhang, Y.; Alsop, R.J.; Soomro, A.; Yang, F.G.; Rheinstandter, M.C. Effect of shampoo, conditioner and permanent waving on the molecular structure of human hair. Peer] 2015, 3, e1296. [CrossRef] [PubMed]

40. Robinson, V.N.E. A study of damaged hair. J. Soc. Cosmet. Chem. 1976, 27, 155-161. [CrossRef] [PubMed]

41. Cruz, C.F.; Martins, M.; Egipto, J.; Osorio, H.; Ribeiro, A.; Cavaco-Paulo, A. Changing the shape of hair with keratin peptides. RSC Adv. 2017, 7, 5181-51592. [CrossRef]

42. Wang, L.; Ezazi, N.Z.; Liu, L.; Aidary, R.; Xiang, W.; Borghei, M.; Santos, H.A.; Rojas, O.J. Microfibers synthesized by wet-spinning of chitin nanomaterials: Mechanical, structural and cell proliferation properties. RSC Adv. 2020, 10, 29450-29459. [CrossRef]

43. Abd El-Hack, M.; El-Saadoy, M.T.; Shafi, M.E.; Zabermawi, N.M.; Arif, M.; Batiha, G.E.; Khafaga, A.F.; Abd El-Hakim, Y.; Al-Sagheer, A.A. Antimicrobial and antioxidant properties of chitosan and its derivatives and their applications: A review. Int. J. Biol. Macromol. 2020, 164, 2726-2744. [CrossRef]

44. Hart, H. Minireview of waste shell-derived materials' application. Sustain. Circ. Econ. 2020, 38, 514-527. [CrossRef]

45. Harland, D.P.; Walls, R.J.; Vernon, J.A.; Dyer, J.M.; Woods, J.L.; Bell, F. Three-dimensional architecture of macrofibrils in the human scalp hair. J. Struct. Biol. 2014, 185, 397-404. [CrossRef]

46. Panariello, L.; Coltelli, M.B.; Buchignani, M.; Lazzeri, A. Chitosan and nano-structured chitin for biobased anti-microbial treatments onto cellulose based materials. Eur. Polym. J. 2019, 113, 328-339. [CrossRef]

47. Muriel, J.M.; O’Neill, A.; Kerr, J.P.; Kleinhans-Welte, E.; Lovering, R.M.; Bloch, R.S. Keratin is an integral part of the intermediate filament network in murine skeletal muscle. Am. J. Physiol. Cell Physiol. 2020, 318, C215-C224. [CrossRef] [PubMed]

48. Welte, E. Keratins in Skeletal Muscle: Effects of Altering Expression of Type I/Type II Keratin Pairs. Master's Thesis, Department of Physiology, University of Maryland, Baltimore, MD, USA, 2014.

49. Rittie, L. Cellular mechanisms of skin repair in humans and other mammals. J. Cell Commun. Signal. 2016, 10, 103-120. [CrossRef]

50. Biagini, A.; Zizzi, F.; Santomassi, F.; Orlando, F.; Lucarini, G.; Mattioli-Belmonte, M.; Tucci, M.G.; Morganti, P. Cutaneous absorption of chitin associated with natural synergistic molecules(lutein). J. Appl. Cosmetol. 1999, 26, 69-80.

51. Galbraith, H. Fundamental hair follicle biology and fine fibre production in animals. Animal 2010, 4, 1490-1509. [CrossRef] 
52. Coloumbe, P.A.; Omary, M.B. Hard and soft principles defining the structure, function and regulation of keratin intermediate filaments. Curr. Opin. Cell. Biol. 2002, 14, 110-122. [CrossRef]

53. Sellan, K.; Rajan, S.; Suganya, T.; Parameshwari, G.; Antonysamy, M. Immunocosmeceuticals by anti-hair antibodies. Chron. Young Sci. 2013, 4, 81-85.

54. Speck, O.; Speck, T. An overview of bioinspired and biomimetic self-repairing materials. Biomimetics 2019, 4, 26. [CrossRef] [PubMed]

55. Morganti, P.; Morganti, G. Natural polymers for natural hair: The smart use of an innovative carrier. In Nanocosmetics: Fundamantals, Applications and Toxicity; Nanda, A., Nanda, S., Nguyen, T.A., Rajendran, S., Slimani, Y., Eds.; Elsevier: Amsterdam, The Netherlands, 2020; pp. 267-286.

56. Morganti, P.; Danti, S.; Coltelli, M.B. Chitin and lignin to produce biocompatible tissues. Res. Clin. Dermatol. 2018, 1, 5-11. [CrossRef]

57. Danti, S.; Trombi, L.; Fusco, A.; Azimi, B.; Lazzeri, A.; Morganti, P.; Coltelli, M.B.; Donnarumma, G. Chitin nanofibrils and nanolignin as functional agents in skin regeneration. Int. J. Mol. Sci. 2019, 20, 2669. [CrossRef] [PubMed]

58. Morganti, P. Use of chitin nanofibrils from biomass for an innovative bioeconomy. In Nanofabrication Using Nanomaterials; Ebothe, J., Ahmed, W., Eds.; One Central Press: Manchester, UK, 2016; pp. 1-22.

59. Morganti, P.; Del Ciotto, P.; Stoller, M.; Chianese, A. Antibacterial and antiinflammatory green nanocomposites. Chem. Eng. Trans. 2016, 47, 61-64. [CrossRef]

60. Donnarumma, G.; Fusco, A.; Morganti, P.; Palombo, M.; Anniboletti, T.; Del Ciotto, P.; Baroni, A.; Chianese, A. Advanced medications made by green nanocomposites. Int. J. Res. Nano Sci. 2018, 5, 261-270.

61. Morganti, P.; Fusco, A.; Paoletti, I.; Perfetto, B.; Del Ciotto, P.; Donnarumma, G. Anti-inflammatory, immunomodulatory, and tissue repair activity on human keratinocytes by green innovative nanocomposites. Materials 2017, 10, 843. [CrossRef] [PubMed]

62. Lee, S.C.; Yoo, E.; Won, K. Preparation and Application of Light-colored Lignin for Broad-spectrum Sunscreens. Polymers 2020, 12, 699. [CrossRef]

63. Morganti, P. Chitin nanofibrils: A natural multifunctional polymer. Physicochemical characteristics, effectiveness and safeness. In Nanobiotechnology; Phoenix, D.A., Ahmed, W., Eds.; One Central Press: Manchester, UK, 2016.

64. Morganti, P. The meaning of nanodimension involving the cosmetic chemist from lab to the industry process. J. Sci. Res. Rep. 2015, 4, 79-100. [CrossRef]

65. Coltelli, M.B.; Aglietto, M. Riutilizzo dei Materiali Polimerici; Nuova Cultura: Rome, Italy, 2015; pp. 39-73.

66. Cinelli, P.; Coltelli, M.B.; Signori, F.; Morganti, P.; Lazzeri, A. Cosmetic packaging to save the environment: Future perspectives. Cosmetics 2019, 6, 26. [CrossRef]

67. Landfill of Waste. Amendments Adopted by the European Parliament on 14 March 2017 on the Proposal for a Directive of the European Parliament and of the Council Amending Directive 1999/31/EC on the Landfill of Waste. Available online: https: / / eur-lex.europa.eu/legal-content/EN/TXT/PDF/?uri=CELEX:52017AP0071\&rid=9 (accessed on 12 April 2019).

68. Ehilen, O.; Obadoni, B.; Imade, F.; Eseigbe, D.; Mensah, J.K. The effect of detergents on the germination and growth of Amaranthus hybridus L. and Solanum lycopersicon L. Niger. Ann. Nat. Sci. 2017, 16, 100-108.

69. Fatoba, P.O.; Olorunmaiye, K.S.; Adepoju, A.O. Effects of soaps and detergents wastes on seed germination, flowering and fruiting of tomato (Lycopersico nesculentum) and okra (Abelmoschus esculentus) plants. Ecol. Environ. Conserv. 2011, 17, 7-11.

70. Alvarenga, P.; Palma, P.; Goncalves, A.P.; Fernandes, R.M.; Cunha-Queda, A.C.; Duarte, E.; Vallini, G. Evaluation of chemical and ecotoxicological characteristics of biodegradable organic residues for application to agricultural land. Environ. Int. 2007, 33, 505-513. [CrossRef]

71. Position of European Bioplastics Concerning Bioplastics and the Circular Economy. Available online: https://www.pac.gr/bcm/ uploads/bioplastics-and-the-circular-economy.pdf (accessed on 6 January 2019).

72. Cinelli, P.; Coltelli, M.B.; Mallegni, N.; Morganti, P.; Lazzeri, A. Degradability and Sustainability of Nanocomposites Based on Polylactic Acid and Chitin Nano Fibrils. Chem. Eng. Trans. 2017, 60, 115-120.

73. Aklog, Y.F.; Egusa, M.; Kaminaka, H.; Izawa, H.; Morimoto, M.; Saimoto, H.; Ifuku, S. Protein/CaCO $3 / \mathrm{chitin}$ nanofiber complex prepared from crab shells by simple mechanical treatment and its effect on plant growth. Int. J. Mol. Sci. 2016, 17, 1600. [CrossRef] [PubMed]

74. Boukhlifi, F.; Mamouni, F.Z.; Razouk, R. Chitin/Chitosan's Bio-Fertilizer: Usage in Vegetative Growth of Wheat and Potato Crops; IntechOpen: London, UK, 2018. [CrossRef]

75. Coltelli, M.B.; Cinelli, P.; Gigante, V.; Aliotta, L.; Morganti, P.; Panariello, L.; Lazzeri, A. Chitin nanofibrils in poly(lactic acid) (PLA) nanocomposites: Dispersion and thermo-mechanical properties. Int. J. Mol. Sci. 2019, 20, 504. [CrossRef]

76. Herrera, N.; Salaberria, A.M.; Mathew, A.P.; Oksman, K. Plasticized polylactic acid nanocomposite films with cellulose and chitin nanocrystals prepared using extrusion and compression molding with two cooling rates: Effects on mechanical, thermal and optical properties. Compos. Part A 2016, 83, 89-97. [CrossRef]

77. Coltelli, M.B.; Aliotta, L.; Vannozzi, A.; Morganti, P.; Panariello, L.; Danti, S.; Neri, S.; Fernandez-Avila, C.; Fusco, A.; Donnarumma, G.; et al. Properties and skin compatibility of films based on poly(lactic acid) (PLA) bionanocomposites incorporating chitin nanofibrils (CN). J. Funct. Biomater. 2020, 11, 21. [CrossRef] [PubMed]

78. Aliotta, L.; Vannozzi, A.; Canesi, I.; Cinelli, P.; Coltelli, M.B.; Lazzeri, A. Poly(lactic acid) (PLA)/Poly(butylene succinate-coadipate) (PBSA) compatibilized binary biobased blends: Melt fluidity, morphological, thermo-mechanical and micromechanical analysis. Polymers 2021, 13, 218. [CrossRef] 
79. Narancic, T.; Verstichel, S.; Reddy Chaganti, S.; Morales-Gamez, L.; Kenny, S.T.; De Wilde, B.; Babu Padamati, R.; O'Connor, K.E. Biodegradable plastic blends create new possibilities for end-of-life management of plastics but they are not a panacea for plastic pollution. Environ. Sci Technol. 2018, 52, 10441-10452. [CrossRef]

80. Avio, C.G.; Gorbi, S.; Regoli, P. Plastics and microplastics in the oceans: From emerging pollutants to emerged threat. Mar. Environ. Res. 2016, 102, 1-10. [CrossRef]

81. Gavigan, J.; Kefela, T.; Macadam-Somer, I.; Suh, S.; Geyer, R. Synthetic microfiber emissions to landrival those to waterbodies and are growing. PLoS ONE 2020, 15, e0237839. [CrossRef] [PubMed]

82. OECD. Environment at a Glance-OECD Indicators; OECD Publishing: Paris, France, 2020. [CrossRef]

83. OECD. OECD Economic Outlook; OECD Publishing: Paris, France, 2020; Volume 2020. [CrossRef]

84. Morganti, P.; Morganti, G.; Colao, C. Biofunctional textiles for aging skin. Biomedicines 2019, 7, 51. [CrossRef] [PubMed] 